\title{
Augustine on the Varieties of Understanding and Why There is No Learning from Words
}

\author{
Tamer Nawar
}

\section{INTRODUCTION}

This paper examines Augustine's account of understanding and its attainment in De Magistro. Following Myles Burnyeat, ${ }^{1}$ it is often held that Augustine is especially concerned with explanatory understanding (a complex cognitive state characterized by its synoptic nature and awareness of explanatory relations) and that a principal thesis of De Magistro- that there is no learning from words-should be construed not as the claim that testimony is deficient in producing justification in the hearer, but rather as the claim that testimony fails to impart explanatory understanding. Against this view, I argue that in De Magistro Augustine is not in fact especially concerned with explanatory understanding but with various other forms of cognizance (which have hitherto not been clearly characterized or sufficiently distinguished) and that Augustine's claim that there is no learning from words cannot be construed as typically proposed.

I begin by offering a brief, critical account of the received view and observe some of the difficulties it faces (section 2). Next, I distinguish between various different kinds of cognizance which Augustine is interested inwhat I term 'conceptual understanding, ' linguistic understanding,' 'explanatory understanding,' 'spiritual understanding,' and 'infallible knowledge'and examine Augustine's discussion in De Magistro in light of this distinction (section 3). I challenge the traditional interpretation(s) on several points and show that Augustine is initially concerned with basic cognitive states,

1 "Wittgenstein and Augustine De Magistro," Proceedings of the Aristotelian Society 61 (1987), 1-24. 
namely conceptual understanding (a cognitive state constituted by concept possession) and linguistic understanding (a cognitive state constituted by an awareness of the literal meaning of linguistic expressions), while clarifying the precise claims Augustine makes concerning these states. I then argue that when Augustine discusses less basic cognitive states he is not-as is often supposed-discussing explanatory understanding but instead infallible knowledge (a cognitive state which is neither synoptic nor explanatory but is instead characterized by possessing infallible justification).

Finally (section 4), I turn to why Augustine should think that there is no learning from words. Insofar as Augustine is not concerned with explanatory understanding, the standard view does not make intelligible Augustine's thesis: it fails to explain why Augustine thinks these other, nonexplanatory forms of cognizance cannot be satisfactorily attained through testimony. In the case of conceptual understanding, Augustine's point is that while we may, through hearing words and using our imaginations, form a concept of a thing despite never having seen it, such concepts (in contrast to those formed through perception) are not satisfactorily grounded and whether they accurately represent their objects is down to luck; they are-Augustine thinks - epistemically deficient and their attainment does not deserve the name 'learning.' With regard to infallible knowledge (the second of Augustine's principal focal points in the dialogue), the sort of cognizance brought about by testimony also falls short of the kind of knowledge Augustine has in mind. It is attained by a method the reliability of which is less than absolute and, crucially, when one accepts that $p$ on the basis of testimony one does not give independent reflection to whether $p$ and so the reflective grasp of reasons for belief (not, as per Burnyeat, an explanation of the fact believed) required for knowing full well is absent.

\section{THE STANDARD VIEW}

In a seminal article, Myles Burnyeat argued that Augustine took the term scientia, in its strictest and most proper sense, to refer to understanding. Drawing upon Augustine's interchangeable use of the terms 'scire' and 'intellegere' (something which Burnyeat raised with regard to Retractationes 1.14.3), ${ }^{2}$ Burnyeat claimed:

2 "And when I said ... 'What we know, therefore, we owe to reason, what we believe, to authority' (quod scimus igitur, debemus rationi, quod credimus, auctoritati) [Util. Cred. 11.25], this is not to be taken in such a way as to make us frightened in mere ordinary conversation of saying that we know what we believe on adequate testimony. It is true 
If Augustine feels that it makes no odds whether he writes scire or intellegere, that implies that in his view the proper meaning of scire is intellegere. And that in turn explains why he thinks it loose or improper to use 'knowing' (scire) in the ordinary way of what we believe on adequate testimony. Intellegere would not here fit at all. Adequate testimony is excellent justification for believing something, but it does not contribute an understanding of the thing believed ("Wittgenstein and Augustine," 7).

On this view, Augustine uses 'scientia' and 'intellegentia' for the same cognitive state, one which I shall call 'explanatory understanding.' Explanatory understanding seems to be characterized principally by two elements: first, its synoptic nature, it is not directed at single propositions but rather groups of propositions which form, in some sense, a system; and second, it requires an awareness of explanatory relations among said propositions (Burnyeat, "Wittgenstein and Augustine," 20). The paradigm case of such explanatory understanding seems to be that of understanding, as opposed to merely parroting, a mathematical proof (e.g. Burnyeat, "Wittgenstein and Augustine," 21) and the "first-handedness"3 of explanatory understanding is also meant to explain why Augustine (at least in De Magistro $)^{4}$ thinks there is no learning from the words of another:

[Since] Augustine thinks of understanding rather than justification as the differentiating ingredient of knowledge, the main thesis of the De Magistro, that no man can teach another knowledge (scientia), can now be glossed as the claim that no man can teach another to understand something. The argument will not be that information cannot be transmitted from one person to another, but that the appreciation or understanding of any such information is a task that each person must work at for himself. ("Wittgenstein and Augustine," 7-8)

The thought goes that while one may attain (e.g.) justified true belief through accepting the testimony of another, one cannot attain explanatory understanding this way. Testimony is not, on Burnyeat's view, deficient in transmitting justification but in transmitting explanation; explanatory

that when we speak properly (proprie), we say we know only that which we grasp by firm reasoning of the mind. But when we speak in language more suited to common use, as even the Holy Scripture speaks, we should not hesitate to say we know both what we perceive by our bodily senses and what we believe on the authority of trustworthy witnesses, while nevertheless understanding the distance between these and that" (Retr. 1.14.3, tr. Burnyeat, "Wittgenstein and Augustine," 6).

3 E.g. "first-hand learning" (Burnyeat, "Wittgenstein and Augustine," 19); "first-hand appreciation" (ibid., 19); "knowledge must be first hand if it is essentially of connections" (ibid., 21); "like empirical vision, it involves seeing things for oneself" (ibid., 22).

4 In later works (e.g. Ep. 147), Augustine is less negative about testimony and focuses on its virtues rather than its shortcomings. For discussion, see Peter King and Nathan Ballantyne, "Augustine on Testimony," Canadian Journal of Philosophy 39 (2009), $195-214$. 
understanding is something that a person can attain only by seeing how things fit together for him or herself. This is why Burnyeat's Augustine insists that scientia cannot be attained through testimony: "Adequate testimony is excellent justification for believing something, but it does not contribute an understanding of the thing believed" (Burnyeat, "Wittgenstein and Augustine," 7). ${ }^{5}$

The thought attributed to Augustine is attractive and Burnyeat's view has been widely followed. ${ }^{6}$ However, there are several problems which deserve attention. First, Burnyeat appeals to Augustine's interchangeable use of the terms 'scire' and 'intellegere' (or their cognate nouns) as evidence that Augustine was concerned with explanatory understanding. However, while it is fairly uncontroversial that 'intellegere' often means 'understand' it is unclear why the fact that Augustine often uses 'scire' and 'intellegere' interchangeably should indicate that Augustine conceives of scientia (or intellegentia) as explanatory understanding. It is equally compatible with Augustine thinking that intellegentia is no more than scientia, or that some other sort of understanding is at issue, or with Augustine simply being loose in using the relevant epistemic terms.

Secondly, Burnyeat takes Augustine's scientia to be a cognitive state which is explanatory and admits of no piecemeal cognition ("Wittgenstein and Augustine," 20). However, elsewhere (notably in his Contra Academicos) Augustine seems to provide us with non-explanatory, piecemeal instances of cognition as paradigm examples of scientia (e.g. I know this seems white to me, C. Acad. 3.10.23ff.) $)^{7}$ and, as we shall see, in De Magistro Augustine also seems to be concerned with instances of non-explanatory, piecemeal cognition (e.g. my awareness that 'walking' signifies walking, my knowing that a flying man has been seen).

Thirdly, Burnyeat's thesis might explain why testimony is deficient in transmitting explanatory understanding. However, it does not explain why one cannot learn (e.g.) what walking is or what 'walking' means from the

5 Cf. Peter King, "Augustine on the Impossibility of Teaching," Metaphilosophy 29 (1998), 180-2, 190-4.

6 E.g. John Rist, Augustine: Ancient Thought Baptized (Cambridge: Cambridge University Press, 1994), 44-7, 57-60, 87-90; Peter King, "Augustine on the Impossibility of Teaching," 191-3; Gerard O’Daly, "The Response to Skepticism and the Mechanisms of Cognition," in E. Stump and N. Kretzmann (eds.), The Cambridge Companion to Augustine (Cambridge: Cambridge University Press, 2001), 164; Emmanuel Bermon, La signification et l'enseignement: texte latin, traduction française et commentaire $d u$ De magistro de Saint Augustin (Paris: Vrin, 2007), 493-6.

7 Even in mathematics, the paradigm cases of scientia Augustine invokes are not proofs or arguments (as commonly supposed) but rather simple arithmetical operations (e.g. C. Acad. 3.11.25). Though one may know for sure that three threes are nine, it seems much harder to explain why this is so. 
testimony of another. Insofar as Augustine is interested in non-synoptic, non-explanatory kinds of cognizance, the reasons why Augustine thinks they cannot be appropriately attained through testimony is not adequately explained by the standard interpretation.

\section{DE MAGISTRO AND THE VARIETIES OF UNDERSTANDING}

In attempting to provide a more satisfactory account of Augustine's discussion in De Magistro it will be useful to begin by distinguishing the following kinds of cognition which Augustine addresses or might be taken to address:

- Conceptual understanding. To have conceptual understanding of $A$ is to have a concept of $A$ such as to be capable of applying it when appropriate. That is to say, to have a basic form of cognition which allows one to categorize kinds of thing, distinguish between kinds of things, and think of things as belonging to that kind. ${ }^{8}$

- Linguistic understanding. In our terms, this cognitive state is constituted by an awareness of the literal meaning of a meaningful linguistic expression. In Augustine's terms, this is grasping the significate of a sign.

- Explanatory understanding (see above);

- Spiritual understanding. A hitherto largely neglected cognitive state constituted, in Augustine's terms, by grasping the spiritual significate of a sign.

- Infallible knowledge. This cognitive state is similar to how we speak of (infallible) propositional knowledge. If $S$ (infallibly) knows that $p$, then it is necessary that, given the method (evidence, reasons) through which $S$

8 In De Magistro, Augustine speaks of having a concept of $A$ primarily as either having notitia of $A$ (e.g. Mag. 11.34) or of $A$ as being in notitia (e.g. Mag. 11.37). 'Notitia' is used for various forms of cognition; it is elsewhere used to speak of concept possession (e.g. Conf. 11.23.29; Trin. 8.6.9; cf. Duab. An. 8.10, 14.22; B. Vita 4.30; Civ. Dei 10.32, 18.37; C. Faust. 22.56) but also of more sophisticated cognitive states (e.g. Gn. Litt. 5.15.33; En. Ps. 49.18). Notice that what is closest to the standard term for concept is 'notio' (e.g. C. Acad. 1.4.11, 1.5.15; Quant. An. 32.65; Lib. Arb. 1.6.15, 1.13.27, 2.9.26; Conf. 10.14.22, 17.26; Civ. Dei 8.7 [where it renders ' $\epsilon$ 'vvoıa']; Trin. 8.3.4) but Cicero had also used the term 'intelligentia' (e.g. Cic. Fin. 3.21). Notice that there may be different levels of conceptual understanding (e.g. the difference between bare concept possession and conceptual mastery) and different concepts (some more informative others less informative) of the same object. 
came to think that $p, p$. For Augustine, infallible knowledge is also rationally certain and indefeasible. ${ }^{9}$

Several points deserve mention. First, this list is not intended to be exhaustive; secondly, while all these forms of cognizance are seen as the result of the activity of the mind (mens, intellectus) they do seem to be distinct kinds of cognizance; ${ }^{10}$ thirdly, the distinctness of these kinds of cognizance is often neglected in the scholarship; ${ }^{11}$ and finally, none apart from explanatory understanding seem to require an awareness of explanations. ${ }^{12}$ Distinguishing between these cognitive states will be helpful for seeing what is at issue in De Magistro and for providing a framework for seeing what could be at issue. In what follows, I shall challenge traditional interpretations on a number of points. I will first (section 3a) show that in the latter part of De Magistro Augustine is initially concerned with conceptual understanding and linguistic understanding. I will then (section $3 \mathrm{~b}$ ) argue that later in the dialogue (Mag. 11.37) Augustine is discussing infallible knowledge (not explanatory understanding).

9 If $S$ indefeasibly believes that $p$, then $S$ cannot be dissuaded from believing that $p$ (e.g. inconcussum tenere, C. Acad. 1.7.19; cf. C. Acad. 2.9.27; Quant. An. 26.49, 30.58; $E p$. 118.2.12.). If $S$ is certain that $p, S$ believes that $p$ with utter strength and does not entertain any doubts whether $p$ (e.g. C. Acad. 3.10.23; Trin. 15.12.21). For Augustine, these features find their basis in a reflective grasp of reasons (i.e. justification construed in an internalist manner).

10 'Intellectus' may be used of most of these. However, in De Magistro, Augustine most often uses the terms 'notitia' (see n. 7) and 'cognitio.' In other works, 'cognitio' embraces: perceptual beliefs (Quant. An. 24.45); linguistic understanding (Doc. Chr. 2.11.16-14.21); knowing a text (Ep. 118.2.11); historical knowledge (Trin. 12.14.22, 13.1.2); the inner sense's awareness of what to flee and pursue (Div. Qu. 61.4); contemplation as contrasted with action (Vera Rel. 17.33; cf. Div. Qu. 58.2); selfawareness (Gn. Litt. 4.22.39); knowledge of the sciences and arts (Doc. Chr. 2.29.45-30.47); infallible knowledge (e.g. C. Acad. 3.13.29); and various other cognitive states.

11 For instance, the scholarship often speaks of understanding as if understanding the meaning of a word were the same sort of thing as justifiably believing that $p$ or having explanatory understanding (e.g. Burnyeat, "Wittgenstein and Augustine," 17). However, even cognitivist accounts of language typically emphasize that linguistic understanding is very different from justified belief or standard accounts of propositional knowledge (e.g. Noam Chomsky, Knowledge of Language: Its Nature, Origin, and Use (New York: Praeger, 1986), 265-73).

12 For instance, one may have linguistic understanding (something which a parrot lacks) without awareness of explanations (or even of rules). At Doc. Chr. 4.3.4-5 Augustine discusses how an awareness of the rules of eloquence (eloquentia) is not needed for speaking eloquently (and may even be counterproductive); something similar holds of grammatica. 


\section{a. Conceptual Understanding and Linguistic Understanding}

De Magistro begins as an inquiry into the purpose(s) of speaking (loqui). Augustine's interlocutor, his son Adeodatus, initially proposes that we speak either in order to teach (docere) or to learn (discere). In response, Augustine says that he himself thinks that there is a certain kind of teaching that occurs through reminding (commemoratio) and suggests that the purpose of speaking is either to teach or to remind others or ourselves (Mag. 1.1; cf. Doc. Chr. 2.2.3). While some objections are raised to this thesis, the issue of which intentions prompt speaking is not explicitly resolved and the dialogue quickly turns to the nature of words (verba) and signs (signa) (Mag. 2.3ff.) and goes on to take a number of twists and turns. ${ }^{13}$

In the latter half of the dialogue (8.22-13.46) the themes of teaching and learning return to the forefront. Augustine and Adeodatus first give significant attention to ambiguity and something closely resembling the distinction between the use and mention of a term (Mag. 8.22-4). A distinction is also drawn between: signs (signa); things (res); cognizance of signs (cognitio signorum); cognizance of things (cognitio rerum); and how these compare in value (Mag. 9.25-8). In each case the signs discussed are general terms (e.g. 'human,' 'lion,' 'filth,' 'vice') and their significates.

From there, the discussion turns to whether signs play a role in learning. Adeodatus initially proposes that signs are necessary for learning (Mag. 10.29). He argues towards this conclusion by questioning how someone wishing to learn what walking is (quid sit ambulare) might learn this merely from seeing a manifestation of walking (Mag. 10.29). Why, for instance, does one not mistake walking for a very particular kind of walking (e.g. strolling) or a particular amount of walking (unde cavebo, ne id tantum putet esse ambulare quantum ego ambulavero? Mag. 10.29)? The difficulty is provisionally conceded and it is supposed that a learner cannot learn what $A$ is merely from seeing $A$. This being so, Adeodatus supposes that to learn

13 Among the principal questions Augustine addresses concern how signs signify their significates and what the nature of the signifying relation and relata are. Augustine (perhaps merely dialectically) entertains the thought that all words act as proper names and that the meaning of a term is its extension (the so-called "Augustinian picture of language," dubbed so by Wittgenstein). However, elsewhere he seems to favor something like a propositional account of meaning or, alternatively, construes meaning (in Gricean fashion) as the intention of the speaker. For discussion, see Mary Sirridge, "Augustine: Every Word is a Name," New Scholasticism 50 (1976), 183-92; Burnyeat, "Wittgenstein and Augustine," 11-13; Christopher Kirwan, Augustine (London: Routledge, 1989), 35-59; Rist, Augustine, 314-16; Bermon, La signification et l'enseignement, 51-7, 166-218, 278-322. 
what (e.g.) walking is, some signs must be provided (Mag. 10.29-30) and it is provisionally concluded that nothing is taught without signs (confectum est igitur et nihil sine signis doceri, Mag. 10.31).

However, Augustine immediately gives Adeodatus reason to doubt whether this conclusion is correct (Mag. 10.32). He proposes that someone unfamiliar with bird-catching (quisquam ignarus deceptionis avium) and wanting to learn what bird-catching is can learn what bird-catching is merely from observing some instance(s) of bird-catching (Mag. 10.32). This occurs, Augustine tells us, "without a sign" (nullo significatu) simply through the spectator seeing the thing itself (Mag. 10.32). Adeodatus does not see how this advances on what was previously discussed with regard to walking (cf. Mag. 10.29) and complains that the spectator has not been shown the whole of bird-catching (neque enim video et hic totum illud aucupium esse monstratum. Mag. 10.32).

What Adeodatus finds puzzling in both the case of walking and birdcatching is not, as is often thought, how we understand something about a sign. The inquiry is not about how we learn what 'walking' or 'birdcatching' means or how we cut through ambiguity or otherwise attain linguistic understanding but instead how we learn what walking or birdcatching is (e.g. quid sit ambulare, Mag. 10.29). ${ }^{14}$ Not only do these cases concern a world-directed form of cognition (concerning what a thing is) rather than a sign-directed form of cognition (concerning what a sign signifies) but the forms of cognition in question also come about, as Augustine himself emphasizes, without signs (sine signo, Mag. 10.29; nullo significatu [...] nullo signo datur, Mag. 10.32).

Adeodatus' worry centers on the grounding of our concepts; namely, how it is that, from seeing some instance(s) of walking, one forms an appropriate conception of walking which allows one to recognize all instances of walking ("the whole of walking") as instances of walking (Mag. 10.29, 32). Similarly, the bird-catching case concerns how we form a concept of a craft as a whole (Mag. 10.32) merely from seeing some example(s) of it. How is it that, from seeing only some part of the

14 Augustine has here often been taken to offer a close anticipation of Wittgenstein's insights (Phil. Inv. \$26-32) about the ambiguity of ostensive definition, e.g. Burnyeat, "Wittgenstein and Augustine," 12-13; Kirwan, Augustine, 53; Gareth Matthews, Thought's Ego in Augustine and Descartes (Ithaca, NY: Cornell University Press, 1992), 153-8; Gareth Matthews, "Knowledge and Illumination," in E. Stump and N. Kretzmann (eds), The Cambridge Companion to Augustine (Cambridge: Cambridge University Press, 2001), 181; Bermon, La signification et l'enseignement, 58-9, 220-1, $350-3,384-7$. However, this is slightly misleading. There is no ostension, signification, or linguistic act of any kind in these cases; therefore ambiguity, as usually understood, cannot be at issue. 
things which are $F$, we form an accurate conception of $F$-ness? To this question, Augustine replies:

It's easy to get rid of your worry. I add that if he is sufficiently intelligent, he recognizes the kind of craft as a whole on the basis of what he has seen (si ille intellegens esset, ut ex hoc quod uidit totum illud genus artis agnosceret). It's surely enough for the matter at hand that some men can be taught about some things, even if not all, without a sign. (Mag. 10.32) 15

Previously, at Mag. 10.29, it was assumed that $S_{\text {s }}$ forming an adequate conception of walking could not be explained merely by $S$ s seeing some instance(s) of walking. Adeodatus further supposed that if $S$ were to form an adequate conception of walking, then $S$ would have to be presented with certain signs. However, in this case, no signs are presented and instead of attempting to appeal to signs to explain how $S$ attains conceptual understanding, Augustine appeals to $S$ s perceptual acquaintance with $A$ and also $S$ s being intellegens. Adeodatus finds this agreeable; ${ }^{16}$ however, neither Augustine nor Adeodatus pause to consider precisely how this invocation of being intellegens resolves the original difficulty in any detail. Here it suffices to note that Augustine is happy to conclude that many things are learned without signs but simply shown through themselves with no sign being given (nullo signo dato per se ipsa monstrentur, Mag. 10.32).

At this point in the dialogue, Augustine shifts into a long monologue which occupies the rest of the work (Mag. 10.33-14.46). Having previously examined whether learning can occur without signs (and having established that it can), he now turns his attention to examining whether signs can impart learning and goes on to claim that they cannot. Nothing, we are told, is learned or taught simply by means of its sign (nibil [...] per sua signa discatur, Mag. 10.33). To press the point Augustine notes that when one first encounters a (puzzling) word like sarabara, ${ }^{17}$ "the word does not show me what thing it signifies" (Non enim mihi rem, quam significat, ostendit verbum, Mag. 10.33). As put, the claim is ambiguous. It could mean either:

(i) that hearing or reading the linguistic expression ' $A$ ' does not impart understanding of $A$ (i.e. hearing or reading ' $A$ ' does not grant conceptual understanding); or

15 English citations of De Magistro follow Augustine, Against the Academicians and The Teacher, tr. P. King (Indianapolis: Hackett, 1995), sometimes with modifications.

16 "If he is sufficiently intelligent, he'll know the whole of what it is to walk once walking has been illustrated by a few steps" (si enim sit bene intellegens, paucis passibus ambulatione monstrata totum quid sit ambulare cognoscet, Mag. 10.32).

17 For 'sarabara' ('sarabala' in the Vulgate), see G. N. Knauer, "Sarabara. (Dan. 3,94 [27] bei Aug. mag. 10,33-11,37),” Glotta 33 (1954), 100-18. 
(ii) that hearing or reading the linguistic expression ' $A$ ' does not impart understanding of the signifying relation that holds between ' $A$ ' and $A$ (i.e. hearing or reading ' $A$ ' does not grant linguistic understanding).

This ambiguity (cf. note 18) means that in the relevant sorts of locutions it is often not entirely clear whether Augustine is addressing conceptual understanding (knowing what $A$ is) or linguistic understanding (knowing that ' $A$ ' signifies $A$ ). However, what Augustine goes on to say suggests that at this particular point he has in mind (i):

If certain head-coverings are denominated by this name ['sarabarae'], have I learned upon hearing it what the head is or what coverings are? I knew these things before; my conception of them wasn't fashioned because they were named by others, but because I saw them (Ante ista noveram neque cum appellarentur ab aliis, sed cum a me viderentur, eorum est mihi facta notitia). (Mag. 10.33)

Augustine's point is that we do not (and seemingly cannot) learn what (e.g.) head-coverings are simply from hearing the word 'head-covering.' Despite considering whether learning takes place accompanied by a sign, Augustine does not seem to have linguistic understanding in mind but rather conceptual understanding. ${ }^{18}$ We learn what $A$ is (i.e. attain conceptual understanding) not through hearing ' $A$,' but-Augustine thinks - through perceptual acquaintance with $A$ (and, taking into account what was discussed above, the learner being intellegens).

In what immediately follows, Augustine again considers whether a sign shows its significate (and again his discussion is ambiguous). However, this time Augustine does seem to have in mind (ii), that is to say, linguistic understanding:

Suppose that we hear 'head' now for the first time. Not knowing whether that utterance $(v o x)$ is a mere noise or also signifies something, we ask what 'head' is. (Remember we want to have a conception [notitia] not of the thing signified but of the sign itself [non rei quae significatur, sed ipsius signi], which we surely don't have as long as we don't know what it's a sign of.) (Mag. 10.34)

In claiming to desire cognizance of the sign itself (rather than the thing it signifies), Augustine is interested in the sign qua sign and so is concerned

18 One should distinguish between: (1) the difficulty of learning what $A$ is from perceiving $A$; (2) the difficulty of learning what $A$ is from hearing ' $A$ ' (even when accompanied by ostension); and (3) the difficulty of learning what ' $A$ ' signifies from hearing an utterance of ' $A$ ' (even when accompanied by ostension). To think that, because a sign is involved, Augustine must be considering linguistic understanding is probably due to thinking that the only options are (1) and (3) and consequently taking the mention of signs to indicate (3) (when in fact it indicates (2) or (3)). 
with linguistic understanding. ${ }^{19}$ Accordingly, his concern is with how we become aware of the meaning of 'head.' What Augustine wants to emphasize is that conceptual understanding of $A$ is prior to linguistic understanding of ' $A .{ }^{\prime 20}$ One must know what a head is (i.e. one must have the concept HEAD) in order to learn what 'head' means. "We learn the meaning of a word-that is, the signification hidden in the sound-once the thing signified is itself known" (vim verbi, id est significationem, quae latet in sono, re ipsa, quae significatur, cognita discimus, Mag. 10.34). Further, one's (linguistic) understanding of a term or phrase relies upon appropriately applying the relevant concepts (that is what is missing when a parrot utters a phrase).

If attaining linguistic understanding of ' $A$ ' requires having conceptual understanding of $A$, and (at least for the sorts of cases envisioned here) having conceptual understanding of $A$ requires having had perceptual acquaintance with $A$, then attaining linguistic understanding of ' $A$ ' requires having had perceptual acquaintance with $A$.

I wouldn't learn the thing I was ignorant of by the words that he has spoken, but by looking at it (discam rem quam nesciebam, non per verba quae dicta sunt, sed per eius aspectum). This is the way it came to pass that I know and grasp what meaning the name has. When I learned the thing itself, I trusted my eyes, not the words of another - though perhaps I trusted the words to direct my attention, that is, to find out what I would see by looking. (Mag. 10.35)

Thus while words may direct us to look somewhere and see a thing, it is from the seeing (rather than the words) that we learn what the thing is.

In sum, at Mag. 10.29-34 (and seemingly also 8.22-10.29), Augustine focuses on conceptual understanding and linguistic understanding. Of these, conceptual understanding has a more important role than is typically allowed and it seems to be prior to and necessary for linguistic understanding. Neither of these forms of understanding seems to require explanatory awareness and Augustine emphasizes that while perceptual acquaintance is an adequate stimulus for learning what $A$ is (i.e. attaining conceptual understanding), hearing the words of another is not.

19 It is claimed that we cannot attain linguistic understanding of a sign "as long as we don't know what it's a sign of" (Mag. 10.34). This could mean either: (i*) we cannot attain linguistic understanding of ' $A$ ' (i.e. become aware that ' $A$ ' signifies $A$ ) as long as we don't know that ' $A$ ' signifies $A$ (an uninformative tautology); or else (ii*) we cannot attain linguistic of understanding of ' $A$ ' (i.e. become aware that ' $A$ ' signifies $A$ ) as long as we don't know $A$ (i.e. know what $A$ is, have conceptual understanding of $A$ ). I take Augustine's point to be (ii*); this is supported by Mag. 10.34 (see below).

20 The sense of 'priority' here may be temporal but might also indicate dependence or grounding. 


\section{b. Going Beyond Conceptual and Linguistic Understanding}

Until this point in De Magistro (11.36), Augustine has focused on attaining basic forms of cognizance. However, a significant change occurs at Mag. 11.37. Instead of considering how we learn what a thing is or what a term signifies, Augustine turns to a less basic cognitive state: our accepting (accipere) the story of King Nebuchadnezzar (Daniel 3). As the story goes, three boys were thrown into a fire by the king and yet, miraculously, emerged unscathed due to the strength of their faith. An imaginary objector to the thesis that words do not impart understanding asks: do we not learn this story by means of words? Augustine replies:

[1] I will respond that all the things which those words signified were already in our notitia. I'm already familiar with what three boys are, what a furnace is, what a fire is, what a king is, and what being unharmed by fire is, and all the other things that those words signify. [2] Yet Ananias, Azarias, and Misael are just as unknown to me (ignoti mihi) as the sarabarae, and these names didn't help me at all to become acquainted with them, nor could they help me (nec ad eos cognoscendos haec me nomina quicquam adiuuerunt aut adiuuare iam potuerunt). [3] I confess that I do believe rather than know (credere me potius quam scire confiteor) that everything read in the story happened then just as it was recorded. [4] Those on whom we rely were themselves not unaware of the difference. In fact, the Prophet says: "Unless you believe, you shall not understand" (nisi credideritis, non intellegetis). Surely he wouldn't have said this if he had thought there was no difference. (Mag. 11.37)

Augustine begins (in [1]) by talking of the same sort of things as before: concept possession and linguistic understanding. He says that he already had the relevant conceptual understanding-he had the concepts BOY, FIRE, etc. (these were in notitia). He also had the relevant linguistic understanding — he was aware of what 'boy,' 'fire,' etc. signified. Having linguistic understanding of the individual words of which the sentences were composed, Augustine was thereby also able to understand the meaning of the sentences. However, although he had the conception воY and was aware of what 'boy' signified, Augustine stresses (in [2]) that he was not acquainted with the particular boys mentioned in the story (ignoti mihi). Further, the names of the boys ('Ananias,' etc.) did not help him come to know (cognoscere) the relevant individuals (i.e. being able to recognize Ananias, knowing what he is like, etc.). ${ }^{21}$ However, in [3] and [4], Augustine turns to discussing something rather different. In [3], Augustine is no longer concerned with our having a concept воY, or linguistic understanding of 'boy.' Instead, in [3] Augustine talks of his believing that the story 
occurred as described (e.g. believing that the king Nebuchadnezzar threw the boys into the fire) and his prospects of knowing (scire) as opposed to merely believing (credere) these details. In [4], Augustine tells us that the authors of scripture were aware of the difference between merely believing (credere) and understanding (intellegere) and that the former is necessary for the latter (but not vice versa). ${ }^{22}$

On Burnyeat's proposal, Augustine uses 'scire' and 'intellegere' interchangeably in [3] and [4] to discuss the same cognitive state and this cognitive state, which Augustine disclaims in [3], is explanatory understanding. On this view, while hearing the biblical story can impart belief (and even justified belief) that the story occurred as described, explanatory understanding - a cognitive state wherein one must have a synoptic grasp of the relevant domain and be appropriately aware of the whys and the wherefores-cannot be transmitted through testimony (see section 2). Thus one cannot attain explanatory understanding (presumably of the events described by the story) from hearing the story and that is why Augustine thinks there is no learning from words. ${ }^{23}$ So goes the standard interpretation. However, it seems to me that it faces two very significant objections.

First, such an interpretation tells us little about why conceptual understanding and linguistic understanding (the cognitive states which were Augustine's focus until this point in the dialogue and which do not involve awareness of explanatory relations) cannot be learned from words. Second, supposing explanatory understanding to be at issue does not fit the example adduced by Augustine in this part of De Magistro at all well. Prima facie, understanding of a biblical passage is not like understanding a mathematical proof (the paradigm case envisioned by Burnyeat) but even if it were and one allows for the differences between understanding a proof and a biblical story (or the historical event the story is about) it does not seem especially plausible that Augustine is pursuing explanatory understanding here. He is not, after all, concerned with explaining why the king threw the boys into the fire; nor with the motivations of the boys or with how or why their faith saved them from the fire, let alone why (e.g.) the king threw them into the fire as opposed not to throwing them into the fire, or why he

22 In employing the term 'intellegere' it is not immediately clear whether Augustine is drawing an equivalence between intellegentia and scientia (as Burnyeat proposes), using the relevant terms interchangeably, or in fact discussing different cognitive states (and in any case, we should recall Augustine was using the term 'notitia' in [1] and [2]).

23 Cf. Burnyeat, "Wittgenstein and Augustine," 21; King, "Augustine on the Impossibility of Teaching," 180, 193. 
threw them into the fire as opposed to a chasm, etc. or several other matters (such as why God might have ordained things to occur in this manner).

If Augustine is not seeking to understand the whys and the wherefores of the story of King Nebuchadnezzar, what then does he disclaim in [3] when he says he believes (credere) but does not yet know (scire)? The answer, I think, must be either spiritual understanding or infallible knowledge (cognitive states which Augustine shows considerable interest in elsewhere). I'll offer some brief remarks about each and go on to say why I take Augustine to have in mind the latter (i.e. infallible knowledge).

For Augustine, spiritual understanding (e.g. intellectus spiritalis, Ep. 148.4.13, 196.3.9-12; En. Ps. 33.1.7) is a cognitive state attained primarily through the (non-literal) interpretation (tractatio) of the Christian scriptures and is constituted by an awareness of the figurative or spiritual meaning (e.g. sensus spiritalis, Doc. Chr. 4.7.15; cf. secreta significatio, Util. Cred. 7.17) of metaphorical signs (signa translata) and figurative expressions (locutiones figuratae, e.g. Doc. Chr. 2.6.23, 3.24.34). ${ }^{24}$ It is characterized primarily by its ethical aspect and when Augustine discusses it, he emphasizes that the sort of understanding he has in mind is that which enables us to love God and neighbor as we should (e.g. Doc. Chr. 1.36.40, 2.7.10, 3.10.14, 12.18; cf. En. Ps. 31.1.8, 118.11.4, 27.3, 28.7). Accordingly, it has a prominent conative element and certain ethical effects: ${ }^{25}$ it directly informs our wills and, in so doing, is especially efficacious in guiding action (cf. S. Dom. Mon. 2.11.38; En. Ps. 31.1.8, 118.27.3) and plays an important role in making us more virtuous (e.g. Doc. Chr. 2.5.6-7.9). ${ }^{26}$

Although spiritual understanding is often neglected in philosophical scholarship, given that Augustine is here (at Mag. 11.37) discussing

24 Consider the sentence: 'Christ fasted for forty days.' This has a literal meaning: that Christ fasted for forty days. We attain literal linguistic understanding of this linguistic expression when we are aware of this. However, the expression, as it appears in scripture (e.g. Matthew 4: 2), also has a spiritual meaning: that we should abstain from bodily pleasures (Doc. Chr. 2.16.25). We attain spiritual understanding when we become aware of this (cf. Ep. 148.4.13; 157.2.5; 164.2.3). Augustine thinks there is a spiritual meaning (or various spiritual meanings) to be discerned in all of scripture (e.g. Doc. Chr. 3.10.14) and one should note that Augustine is a generous pluralist about the non-literal meaning (s) of scripture (e.g. Conf. 12.31.42-32.43; Doc. Chr. 3.27.38).

25 There are also ethical prerequisites. Augustine stresses that to attain spiritual understanding of scripture our souls must be cleansed (e.g. Doc. Chr. 1.10.10ff., Div. Qu. 48; Util. Cred. 16.34; Civ. Dei 11.2; Trin. 1.13.31; cf. Plot. 1.6.8-9, 3.6.5) and so dedicates the first book of De Doctrina Christiana to discussing ethical notions (e.g. usus and fruitio, Doc. Chr. 1.4.4ff.). Of course, one also needs careful acquaintance with the biblical texts (e.g. Doc. Chr. 2.8.12, 9.14) so as to use the clearer passages to illuminate the less clear (Doc. Chr. 3.16.24; cf. 3.11.17).

26 Cf. En. Ps. 118.11.4, 118.28.7; Div. Qu. 31.1; Ep. Jo. 8.6; S. Dom. Mon. 2.11.38. 
understanding a scriptural story from the Old Testament, that he elsewhere emphasizes that all of the Old Testament must be accepted not only literally but also figuratively (Doc. Chr. 3.22.32), and that qua biblical exegete spiritual understanding often occupies Augustine's attention, we have some reason to suppose that it may be spiritual understanding that is at issue at Mag. 11.37. If that is right, then what Augustine lacked upon hearing the story and what he is disclaiming in [3] was an awarenessroughly speaking — of figurative meaning (which would have special ethical significance). However, while taking Augustine to have spiritual understanding in mind at Mag. 11.37 cannot be ruled out (and it does, I think, fit the text better than the standard suggestion), it also does not seem to be the best interpretative option. In De Magistro Augustine does not mention spiritual understanding or dwell upon the exegesis of scripture; neither are there any gestures towards the ethical import of the biblical story or any significant discussion of those features (just now identified) taken to be characteristic of spiritual understanding.

In fact, instead of spiritual understanding it seems more likely that what Augustine has in mind at Mag. 11.37 is infallible knowledge. Let me say something about this cognitive state and then explain why it fits the text better. That we should think of knowledge as factive reveals why the claim 'Smith knows that $p$, but not- $p$ ' seems absurd (e.g. C. Acad. 3.3.5, 3.4.10; cf. Div. $Q u$. 32). That we should think of knowledge as infallible is meant to reveal why it also seems rather odd to say: 'Smith knows that $p$, but maybe not- $p$.' If $S$ (infallibly) knows that $p$, then it is necessary, given the method through which (or the evidence upon which) $S$ came to believe that $p$, that $p .{ }^{27}$ It is infallible knowledge, rather than (e.g.) explanatory understanding that Augustine seeks to defend in his (roughly contemporary) Contra Academicos when confronted with the sceptical thesis that humans lack knowledge (scientia, e.g. C. Acad. 2.5.11, 3.4.10) and he is often interested in it elsewhere. Infallible knowledge is characterized by infallible justification (more on this below); in contrast to explanatory understanding, it requires no awareness of explanations and need not be synoptic (in

27 Factivity ensures that the person who knows is not mistaken. Infallibility ensures that the person who knows cannot be (or could not have been) mistaken insofar as the method or evidence upon which the belief that $p$ is based guarantees that $p$. I labor the point because the scholarship often either conflates infallibility and factivity or else uses the term 'infallibility' for factivity (e.g. "La définition de la science par l'infallibilité fait l'objet d'un consensus chez les Ancients depuis Plato. S'il y a erreur, par définition la science fait défaut" [Emmanuel Bermon, Le cogito dans la penseie de saint Augustin (Paris: Vrin, 2001), 110]). 
contrast to infallible knowledge, explanatory understanding does not require infallibility). ${ }^{28}$

There is good reason to think that it is infallible knowledge that Augustine is disclaiming in [3]. Looking ahead to slightly later in the dialogue, Augustine emphasizes his point that there is no learning from words by asking: "What if I should say that I had seen a flying man? Do my words then make you as certain as if you were to hear that wise men are better than fools? [...] you know the latter statement with utter certainty (certissime scire)" (Mag. 12.40 [quoted below in full]). His point there is not that he lacked explanatory awareness upon hearing the tale of a flying man (nor that he lacked spiritual understanding) but rather that he cannot know for sure (certissime scire) that it happened. He makes the point often enough with regard to unlikely tales and events of the distant past (e.g. Util. Cred. 11.25; Div. Qu. 48; Ep. 120.2.9-11) and his point at Mag. 11.37 with regard to the biblical story (which seems to fall under both categories) must, I think, be the same. Just as we cannot—on the basis of testimony-know for sure that a flying man has been seen, so too we cannot know for sure that the youths were miraculously saved from the fire (as the biblical story claims). The point is not that we cannot explain the relevant events but that we lack certain proof that they occurred as described. Testimony that $p$ does not eo ipso guarantee that $p$ and thus does not constitute a means of attaining infallible knowledge that $p$.

\section{WHY THERE IS NO LEARNING FROM WORDS}

As we have seen, it turns out that Augustine is not especially concerned with explanatory understanding in De Magistro. Instead, Augustine addresses several kinds of cognizance-namely, conceptual understanding, linguistic understanding, and (at Mag. 11.37, 12.40) infallible knowledge. He seems to claim, of each of these, that they cannot be learned through words. Insofar as these cognitive states are not constituted by explanatory understanding and do not require awareness of explanatory relations, Augustine's claim that there is no learning from words remains in need of explication.

28 Notice that in his Contra Academicos, Augustine's discussion of infallible know-

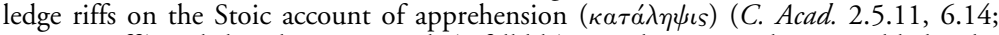
$3.9 .18,21 \mathrm{ff}$.) and that the Stoics took (infallible) apprehension to be attainable but by and large (Posidonius being the notable exception) explicitly distanced themselves from aetiologies and causal explanations (Strabo, Geography 2.3.8). 


\section{a. Attaining Conceptual Understanding and Linguistic Understanding}

Immediately after disclaiming infallible knowledge at Mag. 11.37 (see above), Augustine begins discussing why in both perceiving (sentire) and understanding (intellegere) there is no learning from words. Regarding perception, Augustine's point is simple and straightforward. When we use our bodily senses to perceive, we "consult" (consulere) the bodily senses and their sensible objects (Mag. 12.39). In Augustine's terms, for $S$ to perceive a thing, that thing must be directly present to $S$ ([de sensibilibus $]$ respondemus, si praesto sunt ea quae sentimus, Mag. 12.39; cf. Ep. 147.1.6-2.7). We would agree with this. Perception seems to be such that appropriate (i.e. direct, nondeviant) causation is essential to it. When $S$ perceives that $p$, then the fact that $p$ directly and non-deviantly causes $S$ to think that $p .{ }^{29}$ Testimony precludes such directness.

After making these remarks about perception, Augustine (peculiarly) claims that we cannot directly talk about sensible things which we have previously perceived but are not currently perceiving; instead, we can only talk about the images (imagines) those things leave behind in memoria (Mag. 12.39). ${ }^{30} \mathrm{He}$ goes on to claim:

[1] We carry these images (imagines) in the recesses of our memory in this way as certain attestation (documenta) of things sensed previously [...] [2] If anyone hearing me was then present and sensed these things (sensit ea), he doesn't learn (discere) from my words but knows them again (recognoscere) from the images stored away within himself. [3] If he hasn't sensed them, isn't it obvious that he merely believes (credere) my words rather than learns from them? (Mag. 12.39)

While the precise nature of the imagines (mentioned in [1]) is not entirely clear (they may be picture-like representations but needn't be), ${ }^{31}$ they seem

29 There is a complication. In some early works (though not explicitly in De Magistro) Augustine claims that the soul is not directly affected during such perceptual processes (Mus. 6.5.8; cf. Quant. An. 24.45-25.48; cf. Charles Brittain, "Non-Rational Perception in the Stoics and Augustine," Oxford Studies in Ancient Philosophy 22 (2002), 275-7). Insofar as he offers reasons for this claim, Augustine seems to have conflated the soul being under the yoke of the body (a claim he wishes to deny) with the soul being such as to be causally affected by the body (Mus. 6.5.8). Fortunately he does recognize the obscurity of his thought on this matter (Mus. 6.5.8) and in later works typically emphasizes not so much that the soul is unaffected but (far more plausibly) that it is importantly active in such processes (especially in arranging and uniting information, e.g. conligere, cogere, cf. cogitare, Conf. 10.11.18; Trin. 9.3.3, 11.3.6; Gn. Litt. 12.16.33).

30 For discussion of this (odd) notion, see Gareth Matthews, "Augustine on Speaking from Memory," American Philosophical Quarterly 2 (1965), 157-60.

31 Augustine says they are picture-like (id est imaginem quasi picturam eius, Trin. 8.6.9) but insofar as we have notiones of emotions (e.g. Conf. 10.14.22) and incorporeal 
to be constituents of thought which are either concepts (notiones), constituents of concepts (e.g. a concept might be constituted by some imago or several imagines), or else play a similar role to concepts. If one is to think of $A$, then one needs a notio or imago of $A .{ }^{32}$ The central argument (in [2] and [3]) then seems to be a destructive dilemma. ${ }^{33}$ Suppose that $S$ (the listener) hears $S^{*}$ (the speaker) talk about $A$ (a sensible item). (i) If $S$ had previous perceptual acquaintance with $A$, then $S$ does not learn but may merely "recognize" or "recollect" (recognoscere). (ii) If $S$ did not have previous perceptual acquaintance with $A$, then $S$ does not "learn" but may merely "believe" (credere). But either (i) or (ii). Therefore, when $S$ hears $S^{*}$ talk about $A, S$ does not "learn." 34

Now, the precise sort of cognition which Augustine is claiming words cannot impart is not entirely clear. [2] seems to commit Augustine to the claim that if I am acquainted with (e.g.) cats, then I cannot learn (i.e. attain the relevant form of cognizance) from your words but at most may merely remember (by looking again at my imagines). An unsympathetic reader might see this as absurd. For instance, I understand what a cat is (i.e. have the concept САT) and understand what a parrot is and yet I may certainly learn that Tibbles was a naughty cat from hearing my neighbor utter: "your cat ate my parrot." 35 While the text is not entirely clear, for Augustine's point to be plausible we should suppose that what is at issue is not so much the listener knowing or accepting some particular proposition but rather

things (such as the soul, justice, etc.) and imagines of sounds and tastes (e.g. Conf. 10.10.17), I am inclined not to take this too literally. He also, famously, speaks of them as "inner words" (e.g. Trin. 8.6.9, 9.10.15). I won't say much more here about their possible content or otherwise representative nature (for the Stoic view, which might have influenced Augustine, see Cic. Acad. 2.21).

32 In the Confessiones, Augustine tells us that one needs a concept (notio) of an emotion or sensation if one is to think about or discuss it (Conf. 10.14.22; cf. Lib. Arb. 2.9.26) and the same holds, he thinks, for sensible things and their imagines. If $A$ is something sensible (a stone or the sun are the examples Augustine invokes), then if one is to think about $A$, one must have an image (imago, cf. descriptum, Trin. 12.14.23) of $A$ in one's memoria (Conf. 10.15.23).

33 Augustine's discussion concerns sensible things not currently present. We have already seen that, of present sensible things, Augustine claimed words could advise us where to look but that we learn not from the words but from seeing the thing (e.g. per eius aspectum, Mag. 10.35).

34 Cf. "When words are put forward, either we know (scire) what they signify, or we do not know (nescire); if we know, then it is reminding (commemorari) rather than learning [that words can bring about]; if, however, we do not know, then it is not even reminding, though perhaps there might be some admonishing (admoneri) towards inquiring" (Mag. 11.36).

35 Cf. Norman Kretzmann, "Semantics, History of," in P. Edwards (ed.), The Encyclopedia of Philosophy (New York: Collier Macmillan, 1967), 366. 
the listener coming to be acquainted with the object of that speaker's words (which is indeed suggested by the text). ${ }^{36}$ Thus understood, Augustine's point would be that words cannot lead us to satisfactorily attain new concepts (more on this in a moment). ${ }^{37}$ Supposing Augustine is still discussing the same form of cognition in [3], ${ }^{38}$ the claim would be that whatever cognizance of the relevant sort one does attain from words is deficient (as mere believing is deficient when compared to knowing).

So, why does Augustine think that there is no genuine "learning" from words in such cases? Well, Augustine thinks that some instances of conceptual understanding (those of certain queer properties such as mathematical or moral properties) are not learned from words (or, for that matter, perception) because, quite simply, they do not have to find their way into memoria at all but are instead already there (Conf. 10.10.17, 12.19). ${ }^{39}$

36 Augustine speaks of representations of things (imagines rerum sensarum, documenta rerum) and it is assumed that having an imago of a sensible thing requires having previously perceived that thing (see above).

37 One might think that the speaker does not assert a proposition but simply utters ' $A$,' where ' $A$ ' is a variable for a general term (e.g. 'cat'). Augustine's point would then be that uttering 'cat' is not an adequate stimulus for a listener to learn what cats are (this seems to be how the point is taken by Burnyeat, "Wittgenstein and Augustine," $16 \mathrm{n}$. 18). However, while thus construed Augustine's point is plausible, it renders his thesis both too obvious and too weak to sustain his claim about the inefficacy of words.

38 The talk of believing in [3] makes it sound like a proposition is being put forward and that the learning in question concerns the listener $(S)$ coming to accept that proposition. It is possible that 'believing' refers to a deficient form of conceptual understanding or that there is some fluidity between [2] and [3] in the precise form of cognition or understanding that Augustine has in mind (if the latter, then Augustine is anticipating what I discuss in greater detail below).

39 Cf. Quant. An. 4.5; Lib. Arb. 2.8.20ff.; Gn. Litt. 12.11.22, 24.50; Ep. 147.17.43-4; Trin. 8.6.9. Of sensible objects and emotions, we have imagines and notiones imprinted in our memories. However, in Conf. 10.8.15-9.16, Augustine stresses that we do not have imagines or notiones of the objects of the disciplinae liberales; instead the objects themselves (res ipsas) are themselves present in memoria (cf. Ep. 7.2.4). This has received little discussion but is not easy to make sense of (cf. Luca Castagnoli, "Liberal Arts and Recollection in Augustine's Confessions X (ix 16-xii 19)," Philosophie Antique 6 (2006), 107-35). Prima facie it stipulates that numbers, lines, etc. are themselves in memoria (e.g. Conf. 10.12.19) but it is not clear what that means; later in the book Augustine more plausibly suggests not that it is the objects of these disciplinae that are present but rather the artes themselves (e.g. mathematical skill) (Conf. 10.17.26). Further, in De Libero Arbitrio he seems happy to admit that we do have notiones impressae of numbers, justice, etc. in the soul (i.e. notiones of numbers are present in the soul instead of numbers, justice, etc. themselves, Lib. Arb. 1.6.15, 2.9.26, 15.40). De Trinitate captures his puzzlement on the subject (e.g. sed praesens quiddam cerno, et cerno apud me, etsi non sum ipse quod cerno, Trin. 8.6.9; cf. Trin. 12.14.23). However, whether we have (e.g.) justice itself present in our soul (despite it not making us just) or a notio of justice, it is its conceptual role (e.g. enabling us to think about justice) that Augustine focuses on. Accordingly, I shall use the term 'concept' in these cases. 
Augustine elsewhere says that, in these cases, words merely remind (e.g. Conf. 10.10.17, he may be adverting to this in [3]). However, the problem which is of concern here is why more mundane concepts (e.g. WALKING, BOY, FIRE), i.e. those of sensible things—which are Augustine's principal focus in the earlier part of De Magistro (see section 3a) and are his avowed focus in Mag. 12.39—are such that hearing words from another is not an adequate stimulus to their acquisition and why he should say that we must instead have actually perceived the things themselves (e.g. Mag. 10.33-4).40

Talk of such a perceptual acquaintance requirement is not unique to $D e$ Magistro; the claim is made explicitly in the Confessiones (e.g. 10.16.25) and De Trinitate, where Augustine tells us that it is impossible for us to at all conceive (omnino cogitare) of a color or bodily figure (figura corporis) that we have never seen (Trin. 11.8.14). One might think that this stipulates that we can form imagines of only those things we have actually seen. However, this cannot be what Augustine means. After all, memoria is capable of imagining and in that very discussion in De Trinitate Augustine discusses how the mind has the power to fashion images of things which have not been previously experienced by enlarging, diminishing, and altering those concepts which it has (Trin. 11.5.8; cf. Ep. 7.3.6).

Instead, the perceptual acquaintance requirement should be read generously. Augustine is not claiming that we need to be acquainted with (e.g.) flamingos in order to form a concept of or imagine flamingos but that we require acquaintance with birds, or at least, with bird-like animals (cf. Mus. 6.11.32). In short, there is a limit to imagination. The thought is plausible and is not infrequently made in contemporary discussions of concept acquisition (e.g. by Simon Blackburn). ${ }^{41}$ Augustine's remarks elsewhere

40 Notice that I use the expression 'adequate stimulus' (rather than, e.g., 'cause') because some (e.g. King, "Augustine on the Impossibility of Teaching," 194) seem to assume a sufficiency account of causation (i.e. $A$ causes $B$ iff the presence of $A$ is sufficient for the presence of $B$ ) and take Augustine's claim that there is no learning from words to mean that words do not cause (i.e. are not sufficient for producing) understanding. However, perceiving is also not a cause of (i.e. not sufficient for) understanding (recall the emphasis on the learner's being intellegens, Mag. 10.32 [discussed above]). What must be explained is why perceiving is an adequate stimulus but words are not. Burnyeat generally seems to construe the talk of perceiving as applying, metaphorically, to explanatory understanding (cf. note 3). However, after dwelling on explanation not being transmitted through testimony, he very briefly suggests that Augustine believed in "epistemic categories" ("Wittgenstein and Augustine," 17-18), i.e. that certain things are such that if one knows them, then one has perceived them. This gives a label to Augustine's view but it does not explain why we need to perceive to have the relevant form of cognizance. In what follows I attempt to improve upon this, explaining why Augustine thought this.

41 "With joy or sorrow, we make a first acquaintance with dogs and carrots, and grow into an appreciation of what a Romantic sonata, or a smile, or an electron, is. Growing 
(notably in De Trinitate) suggest this train of thought and the discussion of 'sarabara' earlier in De Magistro (10.33) fits this interpretation well. ${ }^{42}$ Put simply, in order to imagine something complex such as a head-covering, one needs to have concepts of (e.g.) heads and coverings (similarly, imagining a centaur might require the concepts HORSE and MAN).

This suffices to explain the perceptual acquaintance requirement claim and to render it plausible. However, thus understood the perceptual acquaintance requirement merely poses limits on imagination; it does not explain why we cannot learn from words. After all, while one might need to have seen birds or animals, one can imagine a flamingo despite never having seen one on the basis of another's words and so come to possess the relevant concept. Why shouldn't this be considered an instance of learning?

Augustine's answer is not explicitly spelled out in De Magistro but is hinted at elsewhere and seems to turn upon the deficiency of such instances of imagining; they are too vulnerable to epistemic vicissitudes and don't seem to have the right connection with the world to be regarded as a cognitive success. Augustine draws a distinction between two sorts of imagines. Phantasiae are produced by direct perceptual experience; in contrast, phantasmata are produced by imagination (prompted, for instance, by testimony) acting on experience (Mus. 6.11.32; cf. Trin. 8.6.9). ${ }^{43}$ Phantasiae are such that the way they are formed gives a good guarantee that they represent things correctly. In contrast, phantasmata lack such a guarantee; they may well not represent their objects as they are (Augustine tells us this happens only very rarely, Trin. 8.6.7) and whether they do so at all seems to be a matter of luck.

into such an appreciation needs an acquaintance with things. [...] With the acquaintance comes not only an appreciation of what words actually mean, but of the kind of thing they could mean. Acquiring the concept needs learning that there are things which persist in time, which have various clusters of properties, and it requires becoming able to distinguish those things from others on the basis of these properties" (Blackburn, Spreading the Word: Groundings in the Philosophy of Language (Oxford: Oxford University Press, 1984), 56).

42 "If certain head-coverings are denominated by this name ['sarabarae'], have I learned upon hearing it what the head is or what coverings are? I knew these things before; my conception (notitia) of them wasn't fashioned because they were named by others" (Mag. 10.33).

43 Aliter enim cogito patrem meum quem saepe vidi, aliter avum quem numquam vidi. Horum primum phantasia est, alterum phantasma. Illud in memoria invenio, hoc in eo motu animi, qui ex iis ortus est quos habet memoria (Mus. 6.11.32). In De Trinitate, Augustine tells us that in order to think of a city one has perceived, such as Carthage, one uses one's remembered perceptual appearance (phantasia) of Carthage (which one has received through the senses of the body). In contrast, in order to think of a city one has not perceived, such as Alexandria, one uses one's imagined quasi-perceptual appearance (phantasma) (Trin. 8.6.9). 
That testimony cannot serve as an adequate grounding for concepts (while perception can) would seem to be due to the fact that a picture, as they say, is worth a thousand words, i.e. perceiving is a much richer experience and (contra Burnyeat, e.g. "Wittgenstein and Augustine," 7-8 [quoted above]) the linguistic stimulus is deficient in transmitting information. ${ }^{44}$ For instance, I may try to tell you what churidars are (I employ 'churidar' to approximate some of the effects of 'sarabara') by saying something like: "churidars are long trousers, originally from South Asia, which are baggy at the hips but tight at the ankles." Now, you may know what trousers are (know what hips are, etc.) and upon hearing these words you may well imagine something but given the limited information in the linguistic stimulus provided it is - I think — unlikely you would imagine churidars correctly (so as to be able to recognize them upon seeing them) unless you had in fact already seen them (in which case my words would merely remind you of what you had seen). ${ }^{45}$ Further, even if, by luck, one does imagine churidars correctly (without having seen them) from this description (i.e. represent churidars as they really are) and so have cognizance of a sort, it is epistemically deficient much like a lucky guess is. Its accuracy arises not through its grounding but through luck and it would, Augustine thinks, be very rash to suppose that one has imagined correctly (Mus. 6.11.32). Thus understood, it is the inadequate grounding and frequent inaccuracy of concepts formed on testimony that accounts for why Augustine thinks there is no "learning" with regard to this basic form of cognizance and, as the churidar example shows, his point seems to have some merit.

What then of linguistic understanding? Augustine's point here is much briefer. Quite simply, he focuses on our learning of individual words (cf. Burnyeat, "Wittgenstein and Augustine," 16) and, as we have seen, he supposes that conceptual understanding is prior to linguistic understanding. In order to learn what 'cat' signifies, one must already have the relevant concept (СAT). Accordingly, it seems that learning what 'cat'

44 This may seem to attribute to Augustine thoughts like those which motivate Jerry Fodor (and which are attributed by him to Augustine [Jerry Fodor, The Language of Thought (Hassocks: Harvester Press, 1975), 63-4]). However, moderns typically argue that the information present in linguistic stimuli is much less than what is required to cognize the syntactic and semantic rules of language (e.g. Noam Chomsky, Aspects of the Theory of Syntax (Cambridge, Mass.: MIT Press, 1965); Fodor, The Language of Thought). While Augustine might be sympathetic to this, this is not his focus. In De Magistro he is focusing on the acquisition of concepts corresponding to mundane general terms.

45 Augustine thinks that the same point (or a similar point) applies to descriptions of individual persons (cf. Ananias, Azarias, and Misael at Mag. 11.37; the Apostle Paul and Christ at Trin. 8.4.7). 
signifies is akin to merely associating a sonorous label with a concept (e.g. Mag. 10.33; cf. Jo. Ev. Tr. 37.4) and that is why, with regard to linguistic understanding, Augustine says that from words we merely learn the sound or noise of words (Mag. 11.36). ${ }^{46}$

\section{b. A More Complex Form of Cognizance}

At De Magistro 12.40, Augustine moves to consider our acquisition of a different kind of cognizance:

When we deal with things that we see (conspicere) by the mind (mens), namely by the intellect (intellectus) and reason (ratio), we're speaking of things that we look upon immediately in the inner light of Truth, in virtue of which the so-called inner man is illuminated and rejoices. Under these conditions our listener, if he likewise sees these things which his inward and undivided eye, knows what I'm saying from his own contemplation (contemplatio), not from my words. Therefore, when I'm stating truths, I don't even teach the person who is looking upon these truths. He's taught not by my words but by the things themselves made manifest within when God discloses them. (Mag. 12.40)

Augustine here seems to envision words not as teaching us but, at most, as either reminding or admonishing (admonere) us (cf. Mag. 11.36; Conf. 10.10 .17 ) or otherwise prompting (but not causing, cf. note 40) us to "see" with our minds (cf. Mag. 11.38). ${ }^{47}$ What follows strongly suggests that it is infallible knowledge which Augustine has in mind here (witness, for

46 Augustine appreciates that words are composed of sound (sonus) and meaning (intellectus) (S. 28.4; Quant. An. 32.65-6; Conf. 10.26.24). However, when he emphasizes that from words we only learn the sound of words he often also seems to identify words with their sound(s) (e.g. strepitus, Mag. 11.36; personat, Mag. 11.38; sonus verborum, Ep. Jo. 13.3) or else talks of words qua sounds (e.g. et verba ipsa, quod ad sonum adtinet, Imm. An. 15.23).

47 De Magistro contains both talk of reminding (e.g. commemoratio, commemorare, Mag. 1.1-2, 4.7, 7.19-20, 11.36 [quoted above]; cf. admonere, Mag. 9.25, 10.35-11.36, 11.38; recognoscere, Mag. 12.39 [quoted above]) and illumination (e.g. Mag. 11.38-12.40). However, despite early enthusiasm (e.g. Ep. 7.1.2; Quant. An. 20.34; Sol. 2.20.35), in later works Augustine objects to Platonic recollection and employs such talk less frequently because he takes it to imply pre-existence of the soul (it needn't though; it could merely imply innateness of the relevant concepts). Illumination, on the other hand, is a consistent theme in Augustine. He appeals to it when discussing how we cognize a priori truths (e.g. Div. Qu. 46; Lib. Arb. 2.8.21); how we attain spiritual understanding (e.g. En. Ps. 118.18.4); the objective (i.e. non-relativist) nature of truth (e.g. Conf. 12.25.35, Lib. Arb. 2.12.33, 2.19); that cognition requires the aid of God (e.g. En. Ps. 118.18.3-4; Gn. Litt. 12.31.59; Ep. 120.2.10; cf. 2 Cor. 3: 5); and also for other reasons. The controversies are many (especially regarding the precise nature of God's aid) and the details (if indeed such talk can be said to amount to a theory) are difficult to work out. I will say little more here. 
instance, the talk of certainty below) and also sheds some further light onto why such a cognitive state cannot be attained from the words of another:

[1] I might say: "the things I'm saying that you admit to be truths, and that you're certain (certus) of, and that you affirm yourself to know (nosse) — where did you learn them?" Maybe you would reply that I had taught them to you. [2] Then I would rejoin: "What if I should say that I had seen a flying man? Do my words then make you as certain as if you were to hear that wise men are better than fools?" Surely you would deny it and reply that you do not believe the former statement, or even if you did believe it that you do not know it; whereas you know the latter statement with utter certainty (certissime scire). [3] As a result, you would then understand (intellegere) that you hadn't learned anything from my words, neither in the former case (where you did not know although I was asserting it) nor in the latter case (where you knew quite well [optime scire]). (Mag. 12.40)

In [1], Augustine invites us to consider those things we really know (or at least take ourselves to know) and asks how we came by the relevant cognizance. He points out that it seems natural to think that when we heard another assert that $p$ and consequently come ourselves to accept that $p$, that we learned that $p$ from the other person's assertion. However, imagine, Augustine requests in [2], two distinct cases. In the first case, $S$ hears $S^{*}$ assert that $p_{1}$ (e.g. that a flying man has just been seen) but does not give credence to $p_{1}$ (and thus neither knows nor believes that $p_{1}$ ). ${ }^{48}$ In the second case, $S$ hears $S^{*}$ assert that $p_{2}$ (e.g. that the wise are superior to fools) and consequently $S$ comes to accept that $p_{2}$. Finally, in [3], Augustine claims that the preceding considerations show that neither in the first case (where one hears an implausible proposition asserted) nor in the second case (where one hears a plausible proposition asserted) is there learning from words.

Now, to see why there is no learning (i.e. attaining of infallible knowledge, as the talk of certainty strongly suggests) from words, we must, I think, appreciate not only that-due to its being fallible-testimony fails to bring about infallible knowledge, but also that when one relies upon testimony one lacks something more. The first fact-concerning the fallibility of testimony-is simple and plain. As Augustine later points out, people lie, or are deceived, or communicate poorly, or misunderstand, or mishear, and so forth (Mag. 13.41-4) and so the reliability of testimony falls far short of being absolute. However, the point is not just that testimony is fallible (for testimony is hardly distinctive in falling short in

48 Augustine recognizes more explicitly than many that there are degrees of belief or of confidence in a belief that fall short of plena fides (e.g. Civ. Dei 16.31, S. 115.1, Cons. $E v$. 2.28.66). However, for the sake of simplicity, I will here mostly talk of belief as an all-or-nothing affair. 
this way). Rather, it is that testimony does not communicate a reflective grasp of the justification of one's belief. The infallible knowledge Augustine has in mind is not just a cognitive state formed through a method which is absolutely reliable (an account of which could be given in externalist terms), it is also rationally indefeasible and certain (and these are features which require the agent's awareness of the reasons for the relevant belief). ${ }^{49}$ As Augustine elsewhere tells us, this form of cognizance is attained through the firm reasoning of the mind (mentis firma ratione, Util. Cred. 11.25). When one has such infallible knowledge one is also aware of the evidence for this belief and can even respond to the sceptic and say why it is not possible that one is mistaken in the present case. "Knowledge (scientia) doesn't consist merely in the matters that are apprehended. Instead, it consists in the fact that they are apprehended in such a way that nobody should be in error about it or vacillate when pressed by any opponents" (C. Acad. 1.7.19). Augustine recalls this in De Magistro when, in speaking of the relevant form of cognizance, he says of its possessor: "if he were questioned, he could give answers even about these matters" (Mag. 12.40). Fallibility notwithstanding, testimony fails to bring about this reflective grasp of the reasons for one's belief.

Now, consider once more the cases Augustine offers. In the first case, an outrageous assertion (that a flying man had been seen) is made. Augustine highlights the fact that we do not simply accept outrageous things on the basis of testimony. ${ }^{50}$ In this (outrageous) case, the listener would presumably reject the testifier's testimony and, since they have not come to believe that a flying man has been seen, neither would they learn this. Hence in the case of an implausible assertion which is rejected, there is no learning from the speaker's words. However, even if one did put one's negative reasons aside and did come to believe the speaker's report, one should-Augustine points out-recognize that one did not thereby come to acquire knowledge of the relevant sort. Why not? Presumably because even if one were willing to give the testifier the benefit of the doubt, testimony's reliability is less than absolute and one would lack independent positive reasons for believing that $p$ (aside from so-and-so's say-so). In fact, one's negative reasons (i.e. reasons against $p$ ) would render one's belief that $p$ especially tenuous

49 That is to say, the (psychological) certainty and indefeasibility of infallible knowledge is not mere stubbornness but rational certainty and indefeasibility.

50 As presented here, the absence of negative reasons (i.e. reasons to disbelieve that $p$ or the testifier's trustworthiness) is a deciding factor in whether a testifier's assertion that $p$ is accepted (cf. Ep. 147.2.7). In this case, we would probably be inclined to say that testimony is defeasible testimony and either the proposition asserted or the hearer's other beliefs acted as defeaters. 
and uncertain in a manner unfitting for the cognitive achievement Augustine has in mind.

Consider also the second case where a plausible assertion (that the wise are superior to fools) is made. When $S$ accepts $S^{*}$ s testimony Augustine seems to suppose that $S$ s acceptance that $p$ occurs either: (i) because $S$ accepts what $S^{*}$ asserts simply on $S^{* \prime}$ s testimony; or else (ii) because $S$ independently reflects over whether $p$ and it seems, on reflection, to $S$ to be true. ${ }^{51}$

If (i), $S$ 's coming to accept that $p$ because $S^{*}$ asserted it would not (for Augustine) be a case of infallible knowledge. Why not? Because when $S$ accepts another's assertion that $p$ simply on the basis of testimony or trust, $S$ accepts that $p$ without deliberation. $S$ does not give independent reflection to whether $p$ and does not weigh the assertion against his or her other reasons for whether $p$. $S$ is not thereby aware of any independent evidence for thinking that $p$ and does not "consult" (cf. Mag. 11.38) his or her own evidence; instead, $S$ "consults" only the speaker $\left(S^{*}\right)$ and if $S$ were to be asked why they believe that $p$, they would (again) simply say $S^{*}$ told them so. Thus the firm reasoning of the mind and awareness of justificatory grounds which is required for a more elevated form of cognizance is absent.

If (ii), $S$ 's coming to accept that $p$ after hearing $S^{*}$ assert that $p$ might amount to infallible knowledge (if the other conditions are met) but it would not be learning from words. This is because-if it is indeed to be infallible knowledge-although $S^{*}$ has put forward that $p, S$ s acceptance that $p$ has little or nothing to do with the fact that $p$ originates in $S^{*} s$ testimony. Instead, $S$ has instead accepted that $p$ due to independently reflecting upon whether $p$ and considering $p$ on its own merits. $S$ accepted that $p$ not on $S^{*}$ s say-so, but in light of $S$ s own deliberation. It is not the fact that $p$ originated in $S^{*}$ s testimony that convinces $S$ to accept that $p$, rather it is simply $p$, either on its own (as in the case of self-evident truths) or how $p$ fits with $S$ 's evidence (in the case of evident propositions). As Augustine tells us, in such cases the learner is "taught not by my words but by the things themselves made manifest within when God discloses them" (Mag. 12.40 [quoted above]). In accepting $p$ in this way, $S$ is aware of independent grounds for accepting that $p$ and may (if the evidence is good enough) attain infallible knowledge.

In Augustine's terms, when $S$ attains infallible knowledge, $S$ does not do so as a result of "consulting" $S^{*}$ (cf. Mag. 11.38, 12.39). While $S^{*}$ s testimony

51 Augustine does not here envision cases wherein testimony is treated as evidence to be aggregated with our own reasoning. In such cases, one might accept another's testimony that $p$ because one had inferred from the fact that the testifier asserted that $p$, and that this testifier (or testifiers of a similar sort, or testimony in general) usually assert truths, that (ceteris paribus) $p$ is probably true. 
may "admonish" or "remind" (admonere), i.e. give $S$ an opportunity to reflect on whether $p$ (Mag. 11.36, 38), 52 if it is to be infallible knowledge then $S$ "consulted" (consulere, Mag. 12.40) the truth of whether $p$ within themselves (e.g. "he knows what I'm saying from his own contemplation, not from my words," Mag. 12.40 [quoted above]; cf. Conf. 11.3.5).53 Thus Augustine tells us that students "consider within themselves whether truths have been stated. They do so by looking upon the inner Truth, according to their abilities. That is therefore the point at which they learn" (Mag. 14.45). As it is portrayed here, the students look within not in order to explain that $p$, but in order to decide whether to accept that $p$, i.e. for justification. In those cases wherein genuine learning has occurred, $S$ depends upon his or her own reflection and evidence for justification in the belief that $p$. Presumably, if they were later questioned about this belief, the reasons for acceptance of the relevant proposition would-Augustine thinks—-be readily accessible to them and they could publicly justify it. ${ }^{54}$

Thus, in a manner similar to Burnyeat, it must be emphasized that in order to attain scientia, the agent must-in some sense-see how things fit together for themselves (see note 3). However, on Burnyeat's view, Augustine is concerned with explanatory understanding and what testimony fails to impart is explanation: an appreciation of why something is so. In contrast, the interpretation I offer asserts that for Augustine what testimony fails to impart is the right sort of justification, i.e. the right kind of appreciation of why it is right to believe that something is so (something

52 "[...] though perhaps words prompt us to consult Him" (Mag. 11.38 [quoted above]); "though perhaps there might be some admonishing (admoneri) towards inquiring” (Mag. 11.36).

53 In the Confessiones, Augustine imagines speaking to Moses about the creation of the world: "If he [Moses] spoke Latin, I would know what he meant. But how would I know whether he was speaking the truth? If I did know this, I could not know it from him (quod si et hoc scirem, num ab illo scirem). Within me, within the dwelling place of thought, a truth which is neither Hebrew nor Greek nor Latin would speak [... ] It would say: "What he is saying is true" (Conf. 11.3.5; Lib. Arb. 2.12.33; Trin. 3 proem. 2). Augustine can also appeal to inner truth for the attainment of spiritual understanding (e.g. Conf. 12.13.16-15.18) but in De Magistro, as in Conf. 11.3.5, inner truth performs a justifying function.

54 I focus here primarily on admonishing. However, the talk reminding (cf. n. 51) may be similarly explained. For instance, the teacher might say the square of the hypotenuse is equal to the sum of the squares of the other two sides of the triangle. However, the words do not teach us they merely prompt us to examine our concepts (LINE, TRIANGLE, etc.) and if we attain the relevant cognizance it is from this examination. In both cases, the student seems to already "have" the relevant information but merely needs to come to have a different awareness of it or see it under a different mode of presentation (for discussion of this aspect, see King, "Augustine on the Impossibility of Teaching"). 
which Burnyeat explicitly denied). ${ }^{55}$ People who believe that $p$ on the basis of testimony rather than independent reflection will not, Augustine thinks, be able to give good reasons (to themselves or others) for their belief. If faced with questions they will quickly run out of satisfactory answers (cf. C. Acad. 1.7.19; Mag. 12.40) and the relevant cognizance will prove rationally unstable and lack resilience in the face of opposing views. Further, it should be noted that relying on testimony makes one's belief(s) especially vulnerable to that pervasive feature of human interaction: disagreement (if one believes that $p$ because another said that $p$, what will one do when a different person says that not- $p$ ?).

Thus when $S$ hears $S^{*}$ assert that $p$ and $S$ subsequently accepts that $p$, one of two things may have happened. Either $S$ may simply have accepted $S^{*}$ s testimony without reflection, or else $S$ independently reflected over whether $p$ and accepted that $p$ due to the evidence available to them (in which case infallible knowledge may be attained). In the latter case, $S^{*}$ makes an assertion that $p$ but when $S$, in deciding whether to accept it, reflects upon it independently and decides to accept it (owing to this reflection), $S$ did not learn from $S^{*}$ s words but from his or her own reflection.

In the former case, $S$ does not independently reflect over whether $p$ and the most one can attain is fides (aut credere aut opinari, Mag. 12.40). ${ }^{56}$ This sort of cognizance, brought about by testimony, falls short of more elevated cognitive states in several respects but Augustine's focus here seems to be on the fact that it does not have sufficient reliability and lacks an appropriate basis in reasons (i.e. justification in an internalist's sense; cf. quod scimus igitur, debemus rationi, quod credimus, auctoritati, Util. Cred. 11.25) and, thus, rational resilience. ${ }^{57}$ It is thereby vulnerable to counter-evidence (for instance, something as simple as disagreement among testifiers) and may

55 "What is missing [...] is something other than justification" (Burnyeat, "Wittgenstein and Augustine," 7).

56 Fides is justified belief (and often seems to be justified externalistically). Unlike fides, opinio (unjustified belief or wishful thinking) is formed rashly and irresponsibly (through temeritas, e.g. Util. Cred. 11.25). It is the result of an epistemic vice (credulitas) and is usually false and always blameworthy (numquam sine vitio, Util. Cred. 11.25).

57 Christian believers possess warrant and believe truly but their evidence or testimony is not utterly certain proof (indubitata ratio). That is why, in De Utilitate Credendi, they have fides but not scientia (e.g. Util. Cred. 14.32). Being reliant on testimony, we may reliably believe that so-and-so are our parents but we cannot (infallibly) know this (scire, Util. Cred. 10.24-12.26; Div. Qu. 48; cf. F. Invis. 2.4). In later works, Augustine often calls the (fallible and justified in an externalist manner) sorts of cognizance attained through testimony 'cognitio' or 'scientia' (e.g. Retr. 1.14.3 [quoted above]; Gn. Litt. 12.25.52; Trin. 13.1.2, 15.12.21; for discussion, see King and Ballantyne, "Augustine on Testimony"). However, we need not suppose either incoherence (cf. Burnyeat, "Wittgenstein and Augustine," 19 n. 23) or a radical change in his conception of scientia (or of testimony). Even in later works Augustine thinks there is a sense of 'scientia' which 
even fall apart under sustained questioning. This is not to say that cognizance brought about by testimony is without worth. Even in early works it enjoys a positive epistemic status and Augustine often emphasizes both its usefulness (cf. Mag. 13.41, 14.46) and that one should typically accept another's testimony. ${ }^{58}$ However, even notwithstanding the fallibility of testimony, cognizance brought about by accepting testimony falls short of knowing full well (optime scire) and its acquisition does not-Augustine thinks—deserve the name 'learning' (cf. Mag. 14.45 [quoted above]).59

\section{CONCLUSION}

Following Burnyeat, it is commonly thought that in De Magistro Augustine is especially interested in explanatory understanding and that his thesis that there is no learning from words should be glossed as the claim that explanatory understanding cannot be transmitted through testimony. I have sought to offer a more fine-grained discussion of Augustine's account. In the first instance, in De Magistro Augustine is concerned with a variety of cognitive states. He initially focuses on more basic cognitive states-conceptual understanding (understanding what $A$ is, having a concept of $A$ ) and linguistic understanding (understanding what ' $A$ ' signifies). When he turns his attention to more complex forms of cognizance (e.g. at Mag. 11.37, 12.40), it seems that he has infallible knowledge (rather than explanatory understanding) in mind. Augustine's thinking as to why there is no learning from words is also more complex than has hitherto been appreciated. With regard to conceptual understanding, there is no learning from words because, in contrast with (e.g.) perceiving, words are insufficiently informative to serve as satisfactory grounding for conceptual understanding. Concepts attained this way are frequently inaccurate and even when they represent their objects accurately this is down to luck. With regard to linguistic understanding, Augustine thinks that words teach us

signifies infallible knowledge (e.g. Ep. 120.2.9-11; Retr. 1.14.3; cf. Trin. 15.12.21) and this does not seem to be such as to come about through testimony.

58 It is not entirely clear whether the sense of 'should' is strictly epistemic because Augustine seems to take doxastic deliberation to be informed by non-epistemic reasons. For instance, when an unreliable friend speaks I may have little epistemic reason to believe him (cf. Ep. 147.2.7) but caritas may compel me to (e.g. caritas omnia credit, Conf. 10.3.3; cf. F. Invis. 2.3-4).

59 Even in later works Augustine emphasizes that fides is to act as scaffolding for more elevated cognitive states (e.g. fides enim gradus est intellegendi; intellectus autem meritum fidei, S. 126.1.1, 6.8; cf. S. 139.1.1). At most it marks the start of a learning process; not its completion. 
only the "sound" or "noise" of words (merely attaching a sound to a concept already possessed). Finally, he thinks that accepting that $p$ on the basis of another's assertion that $p$ fails to produce the rational certainty and indefeasibility required by knowing full well. Being fallible, testimony does not bring about infallible knowledge (one cannot, on the basis of testimony that $p$ rule out that not $-p$ ) and depending upon another's testimony fails to lead one to the reflective grasp of reasons required by such knowledge. ${ }^{60}$

University of Oxford

\section{BIBLIOGRAPHY}

Augustine. Against the Academicians and The Teacher, tr. P. King (Indianapolis: Hackett, 1995).

Augustine. Contra Academicos, De Beata Vita, De Ordine, De Magistro, De Libero Arbitrio, ed. W. M. Green and K. D. Daur (Turnhout: Brepols, 1970).

Augustine. De Trinitate libri quindecim, ed. J. W. Mountain (Turnhout: Brepols, 1968).

Bermon, Emmanuel. La signification et l'enseignement: texte latin, traduction française et commentaire du De magistro de Saint Augustin (Paris: Vrin, 2007).

Bermon, Emmanuel. Le cogito dans la penseie de saint Augustin (Paris: Vrin, 2001).

Blackburn, Simon. Spreading the Word: Groundings in the Philosophy of Language (Oxford: Oxford University Press, 1984).

Brittain, Charles. "Non-Rational Perception in the Stoics and Augustine," Oxford Studies in Ancient Philosophy 22 (2002), 253-308.

Burnyeat, Myles. "Wittgenstein and Augustine De Magistro," Proceedings of the Aristotelian Society 61 (1987), 1-24.

Castagnoli, Luca. "Liberal Arts and Recollection in Augustine's Confessions X (ix 16-xii 19)," Philosophie Antique 6 (2006), 107-35.

Chomsky, Noam. Aspects of the Theory of Syntax (Cambridge, Mass.: MIT Press, 1965).

Chomsky, Noam. Knowledge of Language: Its Nature, Origin, and Use (New York: Praeger, 1986).

Fodor, Jerry. The Language of Thought (Hassocks: Harvester Press, 1975).

King, Peter. "Augustine on the Impossibility of Teaching," Metaphilosophy 29 (1998), 179-95.

King, Peter and Nathan Ballantyne. "Augustine on Testimony," Canadian Journal of Philosophy 39 (2009), 195-214.

Kirwan, Christopher. Augustine (London: Routledge, 1989).

60 I would like to thank Luca Castagnoli and an anonymous referee for Oxford Studies in Medieval Philosophy for very helpful criticisms and suggestions on earlier versions of this piece. 
Knauer, G. N. "Sarabara. (Dan. 3,94 [27] bei Aug. mag. 10,33-11,37)," Glotta 33 (1954), 100-18.

Kretzmann, Norman. "Semantics, History of," in P. Edwards (ed.), The Encyclopedia of Philosophy (New York: Collier Macmillan, 1967), 358-406.

Matthews, Gareth. "Augustine on Speaking from Memory," American Philosophical Quarterly 2 (1965), 157-60.

Matthews, Gareth. "Knowledge and Illumination," in E. Stump and N. Kretzmann (eds), The Cambridge Companion to Augustine (Cambridge: Cambridge University Press, 2001), 171-85.

Matthews, Gareth. Thought's Ego in Augustine and Descartes (Ithaca, NY: Cornell University Press, 1992).

O'Daly, Gerard. "The Response to Skepticism and the Mechanisms of Cognition," in E. Stump and N. Kretzmann (eds), The Cambridge Companion to Augustine (Cambridge: Cambridge University Press, 2001), 159-70.

Rist, John. Augustine: Ancient Thought Baptized (Cambridge: Cambridge University Press, 1994).

Sirridge, Mary. "Augustine: Every Word is a Name," New Scholasticism 50 (1976), 183-92.

Strabo. Geography, tr. H. L. Jones, 8 vols (Cambridge, Mass.: Harvard University Press, 1917-33).

Wittgenstein, Ludwig. Philosophical Investigations: The German Text, with a Revised English Translation (Oxford: Blackwell, 2001). 